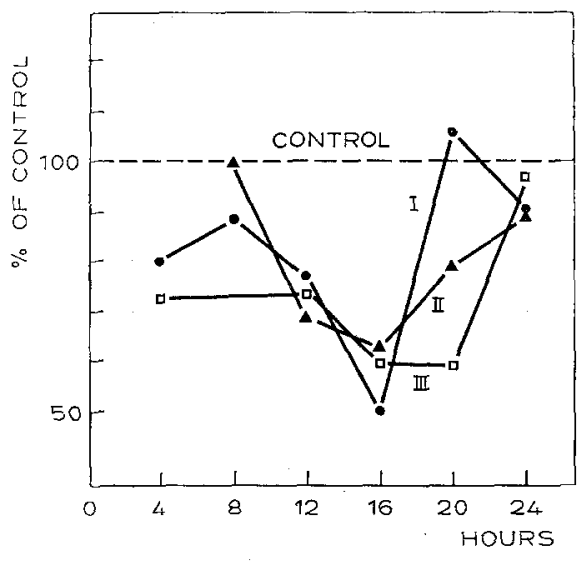

Fig. 1. Effect of three independently produced liver extracts $(I=200 \mathrm{mg} / 100 \mathrm{~g}$ body weight; $I I, I I I=400 \mathrm{mg} / 100 \mathrm{~g}$ body weight; subcutaneously) upon ${ }^{3} \mathrm{H}$-thymidine incorporation $(50 \mu \mathrm{Ci} / 100 \mathrm{~g}$ body weight, i.p.) in the liver of adult SpragueDawley-rats $(0,200 \mathrm{~g})$. The extracts are given at time 0 . In all three experiments the effect as compared to the corresponding controls is statistically validated (double variance analysis, $p<0,05)$. Each point represents the mean value from 3 animals $(n=48)$. The broken line represents the mean values of the corresponding controls $(=100 \%, n=48)$

to nervous and hormonal regulation, growth is controlled by tissue-specific, intracellular inhibiting factors. The existence of such intracellular inhibiting substances has indeed been reported in epidermis, in sebaceous glands, in granulocytes and in lymphocytes (see [3]), and there are indications of their presence in the liver $[4,5]$. These findings have been questioned by some authors $[3,6,7]$. We therefore undertook an investigation designed to find out whether tissue-specific intracellular inhibiting factors play a role in the regulation of growth in the liver.

We used ${ }^{3} \mathrm{H}$-thymidine incorporation and liquid scintillation counting to measure the rate of DNA synthesis [3] in order to determine the effect of liver extracts on the physiological regeneration of the liver in adult rats. The extracts were prepared from rat liver by the process normally employed to extract "epidermal chalone" [3]: The tissue was homogenized in distilled water and freeze-dried. $1 \mathrm{~g}$ (dry weight) of homogenate was dissolved in $10 \mathrm{ml}$ of distilled water and extracted at $4{ }^{\circ} \mathrm{C}$ in a nitrogen atmosphere for $30 \mathrm{~min}$. After centrifugation the sediment was again extracted with distilled water ( $1 \mathrm{~g}$ in $5 \mathrm{ml}$ ) and the combined extracts were freeze-dried.

Preliminary experiments had shown that in order to obtain any observable effect, a concentration of 200 or $400 \mathrm{mg}$ of extract per $100 \mathrm{~g}$ body weight (injected subcutaneously) is required. In Fig. 1 the incorporation of ${ }^{3} \mathrm{H}$-thymidine in the liver after injection of liver extracts is plotted as a percentage of the corresponding controls. In three experiments a marked inhibition of ${ }^{3} \mathrm{H}$-thymidine incorporation was observed with a maximum at $16 \mathrm{~h}$ after application to the extracts. In order to test whether the effect was specific to liver extracts, we investigated the effects of other tissue extracts on the liver in the same manner. Extracts from both kidney and lung exhibited the same degree of inhibition on the liver as liver extract. This test system thus failed to demonstrate the presence of a tissue-specific inhibiting factor ("hepatic chalone") in the liver. These results are in agreement with those reported for young and partially hepatectomized rats $[3,7]$.

Received April 17, 1973

[1] Weiss, P., Kavanan, J. L.: J. Gen. Physiol. 41, 1 (1957). [2] Bullough, W. S.: Cancer Res. 25, 1683 (1965). - [3] Volm, M., Mattern, J., Wayss, K.: Exp. Path. 7, 84 (1972). - [4] Saetren, H. A.: Exp. Cell Res. 11, 229 (1956). - [5] Verly, W. G., et al.: Canad. J. Biochem. 49, 1376 (1971). - [6] Volm, M.: Habil.-Schrift, Universität Heidelberg. (1971) - - [7] Spielhoff, R.: Proc. Cos. exp. Biol. (N.Y.) 138, 43 (1971)

\section{Antibody Against Ir-Region Controlled Antigen in Mice}

D. Götze ${ }^{1}$, R. A. Reisfeld ${ }^{2}$ and J. Klein ${ }^{3}$

Institut für Hämatologie der Gesellschaft für Strahlen- und Umweltforschung mbH, München ${ }^{1}$, Scripps Clinic and Research Foundation, La Jolla/California ${ }^{2}$ and School of Dentistry, University of Michigan, Amn Arbor/Michigan ${ }^{3}$

The major histocompatibility complex $(H-2)$ of the mouse consists of four regions: $H-2 K, I r, S s$ and $H-2 D$ [1]. We use four small letters to in dicate the genetic origin of these regions. For instance, the $H-2^{a}$ chromosome carried by strain B10.A is designated $k k d d$; its $H-2 K$ and $I \gamma$ regions are derived from the $H-2^{k}$ chromosome and its $S s$ and $H-2 D$ regions from the $H-2^{d}$ chromosome.

The $H-2 K$ and $H-2 D$ region genes code for the cell surface antigens ( $\mathrm{H}-2$ antigens) responsible for graft rejection and these antigens are involved in the production of typical $\mathrm{H}-2$ antibodies. All of the known $\mathbf{H}-2$ antigens seem to be determined by these two regions. The $S s$ region codes for certain protein antigens in the serum of normal mice [2]. There is evidence associating $I r$ region with at least three different functions: it controls the level of antibody response to certain synthetic polypeptides [3] and apparently also to a variety of other antigens $[4,5]$; it determines the degree of stimulations in mixed-lymphocyte culture (MLC) [6]; and it determines the intensity of graft-versus-host (GVH) reactions [7]. All three functions involve thymus-derived lymphocytes ( $T$. cells) and the $T$ cells play a crucial role in the initial stages of an immune response, i.e. antigen recognition. There has thus been speculation that the $I r$ region codes for antigen-recognition structures on the surface of $T$ cells [5]. The discovery of such recognition structures (which are not thought to be antibodies in a classical sense [8]) would have far-reaching implications for immunology.

Until recently it was not possible to detect products of the Ir region by means of antibodies, which precluded the investigation of the biochemical nature of these structures. We describe here an antiserum apparently directed against antigens controlled by the $I r$ region of the $H-2^{a}$ chromosome. The antiserum was evoked in $C_{57} \mathrm{BL} / 10 \mathrm{Sn}(\mathrm{B} 10)\left(H-2^{b}\right)$ mice by soluble lymphocyte-membrane antigens (SLMA) prepared from B10.A $\left(H-2^{a}\right)$ cells by salt extraction [9]. B10 mice received $0.1 \mathrm{mg}$ SLMA s.c. with polyadenylic-uridylic acid i.p. as adjuvant once a week for 5 weeks. Cytotoxic antibodie; were first detected in the B10-anti-B10.A-SLMA sera two weeks after the first antigen injection. The serum described in this study was obtained three weeks after the first antigen injection. In the cytotoxic test, this serum gave a positive reaction to the dilution of $1: 24$. Unlike $\mathrm{H}-2$ alloantisera, which usually kill $100 \%$ of the target cells, this antiserum exhibited a reproducible cytotoxicity of only $20 \%$ above the nonspecific background against lymphocytes of spleen or lymph nodes even at the lowest dilution $(1: 2)$. It displayed no such cytotoxicity against bone-marrow cells or thymocytes.

This restricted reactivity suggested that the antiserum might react only with a subpopulation of lymphocytes, namely $T$ cells. It was therefore tested against T-cell-deprived lymphocyte populations: a B10.A lymph-node-cell suspension was treated with anti- $\theta$-serum (AKR-anti-C3H) plus complement, and the surviving cells were reacted with the B10-anti-B10.ASLMA serum. The cytotoxicity of the antiserum was diminished to the background level. The same observation was made with cells of previously thymectomized and anti- $\theta$-serum treated, bone-niarrow-reconstituted $\mathrm{A} / \mathrm{J}$ mice. $(\mathrm{A} / \mathrm{J}$ mice possess the same $H$-2 chromosome as B10.A mice and normal lymphocytes of A/J mice were killed at a level of $20 \%$ above background as B10.A lymphocytes). Conversely, with an elevated percentage of $T$ cells $(80 \% \theta$-positive cells), obtained in lymph-node cell suspensions by purification on Leuko-Pak filter (Julius and Herzenberg, personal communication), the cytotoxic effectiveness of the antiserum rose to $35 \%$ above the nonspecific background. The tissue distribution indicates that the antigen detected by the antiserum is present only on $T$ cells and absent on B lymphocytes (bone-marrow-derived lymphocytes).

To determine the strain distribution of the antigen detected by the B10-anti-B10.A-SLMA antibody, the antiserum was reacted against a panel of cells from selected mouse lines (Table 1). If the above described cytotoxicity pattern of the antiserum was caused by antibodies against $\mathrm{H}-2$ antigens, the 


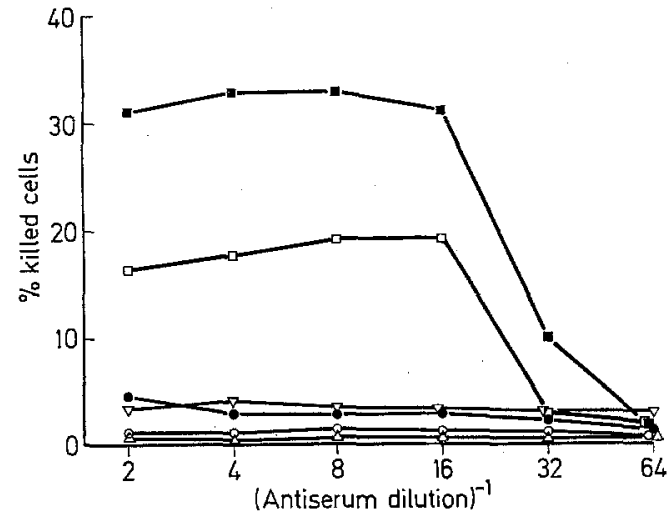

Fig. 1. Cytotoxic reactivity of B10-anti-B10.A-SLMA serum (two-stage test) against lymph-node lymphocytes $(a-0)$, purified $T$ cells of lymph nodes (-), lymph-node cells previously treated with anti- $\theta$-serum plus complement ( $\bullet$, bonemarrow cells $(\nabla-\nabla)$ and thymus cells ( $\Delta-\Delta)$ of B10.A mice, and purified $\mathbf{T}$ cells of lymph nodes of $\mathrm{B} 10\left(\mathrm{o}_{-} \mathrm{o}\right)$ mice. Percentage of killed cells is equal to \% of killed cells in the presence of antiserum minus \% of killed cells in the absence of antiserum

Table 1. Cytotoxicity of B10-anti-B10.A-SLMA serum with lymphocytes of indicated strains

\begin{tabular}{|c|c|c|c|c|c|c|}
\hline \multirow[t]{2}{*}{ Strain } & \multirow{2}{*}{$\begin{array}{l}\text { II-2 } \\
\text { Chromo- } \\
\text { some }\end{array}$} & \multicolumn{4}{|c|}{ Origin of Region } & \multirow{2}{*}{$\begin{array}{l}\text { Maxi- } \\
\text { mum } \\
\text { Kill } \\
(\%)^{a}\end{array}$} \\
\hline & & $H-2 K$ & $I V$ & Ss & $H-2 D$ & \\
\hline $\mathrm{B} 10 . \mathrm{D} 2$ & $\mathrm{~d}$ & $\mathrm{~d}$ & $\mathrm{~d}$ & d & d & 5 \\
\hline B10.A & $\mathrm{a}$ & $\mathrm{k}$ & $k$ & d & d & 35 \\
\hline B10.K & k & $\mathbf{k}$ & $\mathbf{k}$ & $\mathrm{k}$ & $\mathrm{k}$ & 30 \\
\hline A.TE & te & $\mathrm{s}$ & $\mathrm{k}$ & $\mathrm{k}$ & $\mathrm{f}$ & 30 \\
\hline A.SW & $\mathbf{s}$ & s & $\mathbf{s}$ & s & $\mathrm{s}$ & $<5$ \\
\hline B10.M & $\mathrm{f}$ & $\mathrm{f}$ & f & $\mathrm{f}$ & $\mathrm{f}$ & $<5$ \\
\hline B10.HTT & tl & $\mathrm{s}$ & $\mathbf{k}$ & $\mathrm{k}$ & $\mathrm{d}$ & 30 \\
\hline AQR & ya & $q$ & $\mathbf{k}$ & $d$ & $d$ & 30 \\
\hline $\mathrm{B10.A}(4 \mathrm{R})$ & hd & $\mathbf{k}$ & $\mathrm{k} / \mathrm{b}$ & $\mathrm{b}$ & $\mathrm{b}$ & 5 \\
\hline $\mathrm{B} 10 . \mathrm{A}(2 \mathrm{R})$ & he & $\mathbf{k}$ & $\mathrm{k}$ & $d$ & $\mathrm{~b}$ & 25 \\
\hline $\mathrm{B} 10 . \mathrm{A}(5 \mathrm{R})$ & ic & $\mathrm{b}$ & $\mathrm{b}$ & $\mathrm{d}$ & $\mathrm{b}$ & 10 \\
\hline B10 & $\mathrm{b}$ & b & $\mathrm{b}$ & $\mathrm{b}$ & $\mathrm{b}$ & 5 \\
\hline
\end{tabular}

a $\%$ maximum kill of purified lymph-node $\mathrm{T}$ cells $(85 \% \theta$ positive) $=\%$ of killed cells in the presence of antiserum minus $\%$ killed cells in the absence of antiserum.

antiserum should not react with cells of the recombinant strain A.TE $(s k k f)$, as this strain does not possess the $\mathrm{H}-2$ region antigens of the B10.A strain. However, cells of this strain were killed to the same extent as cells of B10.A mice. Cross-reactivity with $\mathrm{H}-2 \mathrm{~K}^{s}$ or $\mathrm{H}-2 \mathrm{D}^{f}$ antigens can be excluded since the antiserum does not kill cells of the strain A.SW(ssss) or B10. $\mathrm{M}(f f f f)$. A further indication that anti-H-2 antibodies are not responsible for the cytotoxicity of the antiserum is provided by the reactivity pattern of the serum against $\mathrm{B} 10 . \mathrm{A}(2 \mathrm{R})(k k d b)$ and $\mathrm{B} 10 . \mathrm{A}(4 \mathrm{R})\left(k k^{\prime}(b b b)\right.$ cells: both strains have the same $\mathrm{H}-2$ regon antigens and share one with B10.A $\left(\mathrm{H}-2 \mathrm{~K}^{k}\right)$; however, only cells of B10.A(2R) mice were killed by the antiserum. Since A.TE mice also carry a different $S$ s region $\left(S s^{k}\right)$ from the immunogen, ie. antigen of B10.A mice $\left(S s^{d}\right)$, it is most unlikely that the antibody is anti-Ss ${ }^{d}$.

There is a common denominator in all strains whose cells were killed by the antiserum: they share all the $I_{y}$ region with B10.A mice, i.e. $\mathrm{A} / \mathrm{J}$ and $\mathrm{B} 10 . \mathrm{A}(k \hbar d d), \mathrm{B} 10 . \mathrm{BR}$ andC BA $(k \hbar k k)$, $\mathrm{B} 10 . \mathrm{A}(2 \mathrm{R})(k k d b), \mathrm{B} 10 . \mathrm{HTT}(s k k d), \mathrm{A} . \mathrm{TE}(s k k f)$ and $\mathrm{AQR}$ $(q k d d)$. This seems to justify the conclusion that the antiserum detects an antigen controlled by the chromosomal segment between the $H-2 K$ and $S$ s regions. The best evidence for this conclusion is provided by the reaction pattern of the pair B10.A(2R) $(k k d b)$ and B10.A(4R) $(k k / b b b)$. These two strains were derived from the same parents by recombination within the $H$ - 2 complex. In the B10.A (4R) strain the crossover occurred within the $I r$ region, whereas in B10.A.2R) the crossover took place between the $S s$ and $H-2 D$ regions [1]. Thus, the two strains differ only in the segment of the chromosome between the $I r$ and $S s$ regions. The B10.A(2R) strain is identical for the Ir region with B10.A, and its cells were killed by the serum; the B10.A(4R) strain is different, and its cells were not killed. The B10.A(2R) cells are known to stimulate B10.A(4R) cells in MLC [6] and GVH reactions [7].

A recently described antigen [5] has properties remarkably similar to the one we described above. It was detected by B10.T $(6 \mathrm{R})(q q d d)$ anti-AQR $(q k d d)$ serum [10] and B10.D2 $(d d d d)$ anti-B10.A-SLMA $(k k d d)$ serum, respectively. It is tempting to speculate that this antigen is related to structures that influence immune response since 1 . it is present only on $T$ cells and not on $B$ cells, 2 . it is controlled by genes closely linked to or identical with the $I r$ region, and 3. it is apparently correlated with MLC and GVH reactivity, as indicated for the pair B10.A(2R) - B10.A (4R).

The authors wish to thank Dr. J. Louis for providing us with thymectomized A/J mice, Dr. J. Chiller for a gift of AKR-anti$\mathrm{C} 3 \mathrm{H}$ serum, and Dr. J. H. Stimpfling for the supply of B10.A (4R) mice. This work was supported by project grant 40 of the Deutsche Forschungsgemeinschaft.SFB 37, University of Munich; and by United States Public Health grant AI 07007.

Received June 5, 1973

[1] Klein, J.: Transpl. Proc. 5, 11 (1973). - [2] Shreffler, D. C., in: Isoantigens and Cell Interaction (J. Palm, ed.). The Wistar Institute Press, Philadelphia, p. 11 (1965). - [3] McDevitt, H. O., et al.: J. exp. Med. 135, 1259 (1972). -- [4] Benacerraf, B., McDevitt, H. O.: Science (Wash. D.C.) 175, 273 (1972). - [5] Lieberman, R., Humphrey, H.: J. exp. Med. 136, 1222 (1972). - [6] Bach, F. H., et al.: Science (Wash. D. C.) 176, 1024 (1972). - [7] Livnat, S., et al.: Nature, New Biology 243, 42 (1973). - [8] Vitetta, E. S., et al.: J. exp. Med. 136, 81 (1972). - [9] Götze, D., Reisfeld, R. A.: J. Immunol. in press. - [10] Hauptfeld, V., Klein, D., Klein, J.: Science (Wash. D. C.), in press. 